\title{
Research Paper An analysis of direction of trade in select Indian agricultural commodities
}

\author{
J. Naipunya, I. Bhavani Devi and D. Vishnusankar Rao
}

See end of the paper for authors' affiliations

Correspondence to :

\section{J. Naipunya}

Department of Agricultural Economics, S.V. Agricultural College, Acharya N.G Ranga Agricultural University, Tirupati (A.P.) India Email: juturu.punya@gmail. com

\section{Paper History :}

Received : 05.06.2020;

Revised : 01.07.2020;

Accepted : 03.08.2020
ABSTRACT : An attempt is made in this paper to assess the dynamics of changes in exports of agricultural commodities namely, maize, chilli and Bengal gram, from India to different export markets by employing Markov chain model. The study is based on a set of countries importing agricultural commodities namely Nepal, others (pooled countries except selected countries) and Bangladesh were the most stable importers of the Indian maize with a probability of retention of 88.52 per cent, 68.90 per cent and 61.09 per cent, respectively. The changing pattern of chilli exports through transitional probability matrices indicated that Thailand, other countries (pooled countries) and Vietnam were stable in importing Indian chilli with a probability of retention of 80.52 per cent, 69.02 per cent and 67.09 per cent, respectively. In case of Bengal gram, Pakistan was one of the stable countries as revealed by a probability of retention of its share i.e., 61.35 per cent. Algeria was also another stable importer as it retained its original share of 45.54 per cent followed by Turkey 41.13 per cent. The overall conclusion that emerges from present study is that Nepal, Thailand and Pakistan turned out to be the most stable countries in respect of importing Indian maize, chilli and Bengal gram.

KEY WORDS : Maize, Chilli, Bengal gram, Direction of trade, Markov chain analysis

How To Cite This PAper : Naipunya, J., Devi, I. Bhavani and Rao, D. Vishnusankar (2020). An analysis of direction of trade in select Indian agricultural commodities. Internat. Res. J. Agric. Eco. \& Stat., 11 (2) : 109-117, DOI : 10.15740/HAS/IRJAES/11.2/109-117. Copyright@2020:Hind Agri-Horticultural Society. 